\title{
Development of Soil Batik Based on Consumer's Needs
}

\author{
Irma Russanti ${ }^{1 *}$, Yulistiana ${ }^{2}$, Mein Kharnolis ${ }^{3}$ \\ ${ }^{123}$ Department of Home Economics, Universitas Negeri Surabaya \\ "Corresponding author,E-mail: Irma.russanti@unesa.ac.id
}

\begin{abstract}
Each Indonesia region has special characteristics of Batik motifs made by the local craftsmen and designers. However, the technical manufacturing is still conventional and less effective, especially the natural coloring process using soil. This study aims to develop a formulation of soil batik design based on consumer needs. This research and development study used interviews and observation as the data collection technique, of which the interviews were carried out for both consumers and batik experts. Results show that soil batik design was developed based on consumer needs including (1) the varieties of motifs covering culinary, prominent local culture, regional characteristic, and local philosophy, (2) different size of main, secondary, and additional motifs, (3) interesting layout, (4) combinative colors usage, and (5) the basic fabric color that should darker color than the motifs' colors. This study suggested that the soil batik developed in this study could be used by Batik craftsmen to vary their products and to enhance their sales.
\end{abstract}

Keywords: Batik motif design, consumer needs, innovation, soil batik

\section{INTRODUCTION}

Batik, one of Indonesia's cultural heritage, has been recognized by UNESCO so that it has been increasingly developed in all layers of Indonesian society. The current government's movement to use local products makes batik more popular. According to the data of Indonesian Ministry of Industry, batik sector has an important role for Indonesia's economy and becomes the largest contributor to foreign exchange. In 2017, the value of batik and weaving exports exceeded 151 Million Dollars. Therefore, batik is a potential commodity both at domestic and abroad. In Indonesian culture, batik coloring technique for clothing materials is considered important as it also determines the prices. Moreover, the high price includes how difficult and attractive the motifs [1]. Batik has traditional classical motifs and beautiful color combinations. It can be identified through its design, color, technique, and meaning beyond the patterns. Development and innovation must continue to be done so that consumers still keep using batik products, encompassing development on motifs and coloring techniques.

Batik coloring can use either natural or synthetic dyes. Natural dyes have many advantages such as low toxicity and allergic reactions, besides biodegradability because they are taken from animal or plant materials without chemical processes [2]. The batik making process using synthetic dyes contains heavy metals. Waste disposal is carried out without further processing. This has a negative impact on the community, especially in terms of environmental health [3]. For this reason, batik coloring is carried out using soil. The development of coloring technique can be performed using combination method between soil and synthetic dyes. Such technique has got its copyright and batik producers in Tulangan Village, Sidoarjo, Indonesia [4].

\section{METHOD}

The method used in the development of soil batik referred to the theory of the creation by Gustami craft art [5] namely the process of exploration, design, and embodiment. With these three stages, the products could be created properly and in accordance with the idea of creation and function [6]. In the exploration process in searching the theme, this study used the theme of local culinary rice cake originated in Sidoarjo. Shellfish had a beautiful skin shape that would be applied as a batik motif as the main motif. The next process was designing the shellfish design as a batik motif. The design included the main, secondary, and additional motifs. Furthermore, the design was made by drawing as a form of reference for the production process. The embodiment of the motifs on the batik cloth was in accordance with the designs that had been made. At last, an evaluation of the product was conducted through an assessment from consumers and batik experts. 


\section{RESULTS AND DISCUSSION}

The theme taken on batik motifs with soil coloring was mussel motif. The dimensions of the shape, size, and texture were very interesting to be used as a source of ideas (look at Figure 1).

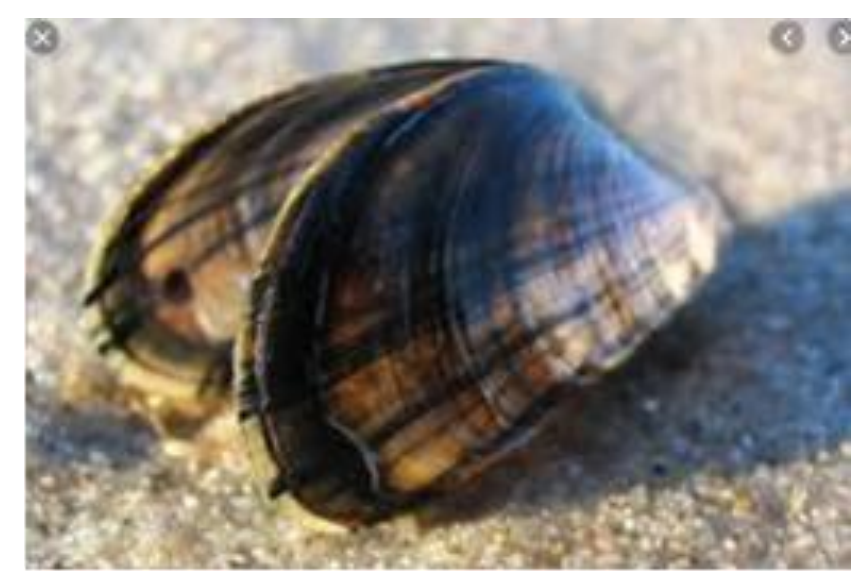

Figure 1. Mussel motif for the batik theme

Based on literature studies, the development of batik design was drawn as follows:

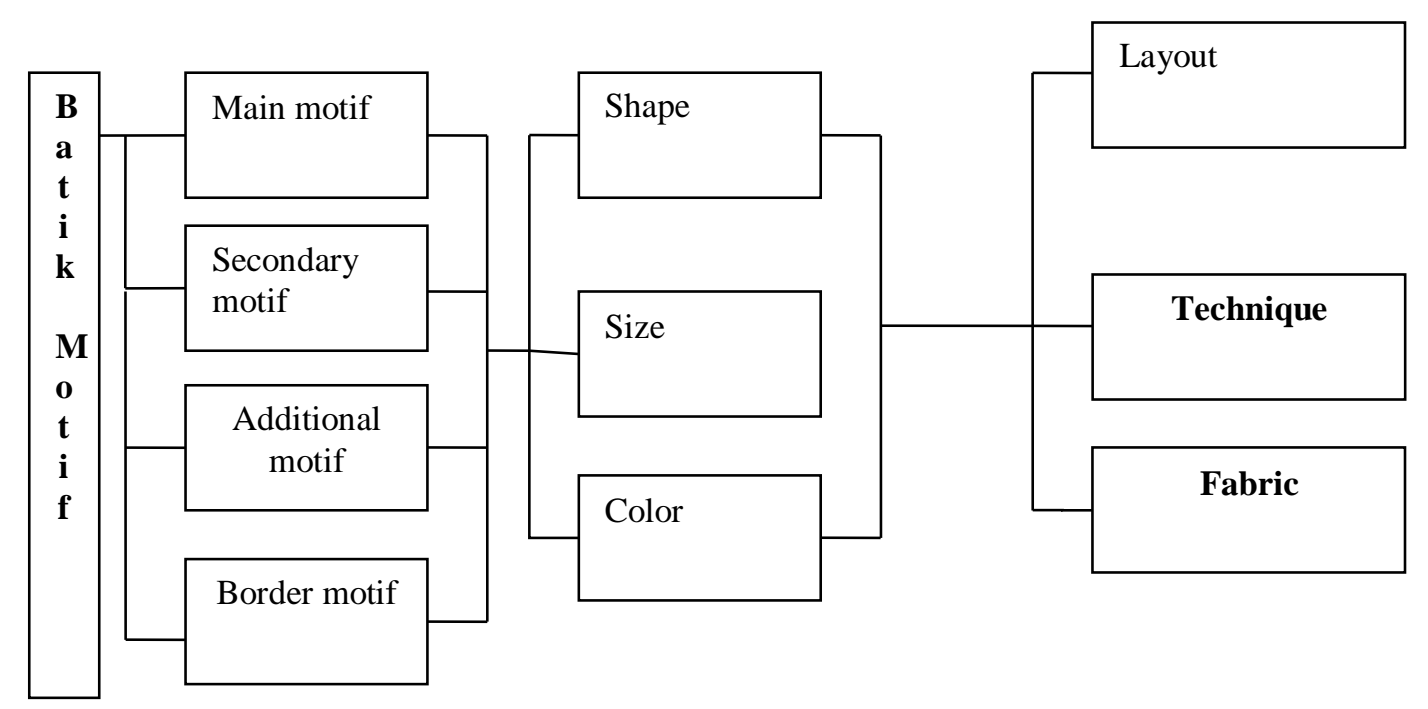

Figure 2. Development of Batik Motif

Batik motifs were developed in main motifs, secondary motifs, and additional motifs as well as considering their shape, size, and color. Afterwards, it was applied through appropriate layout, the batik- making technique, the coloring process, and the textile type. Embodiment of batik motifs applied to the fabric was carried out by soil coloring. 


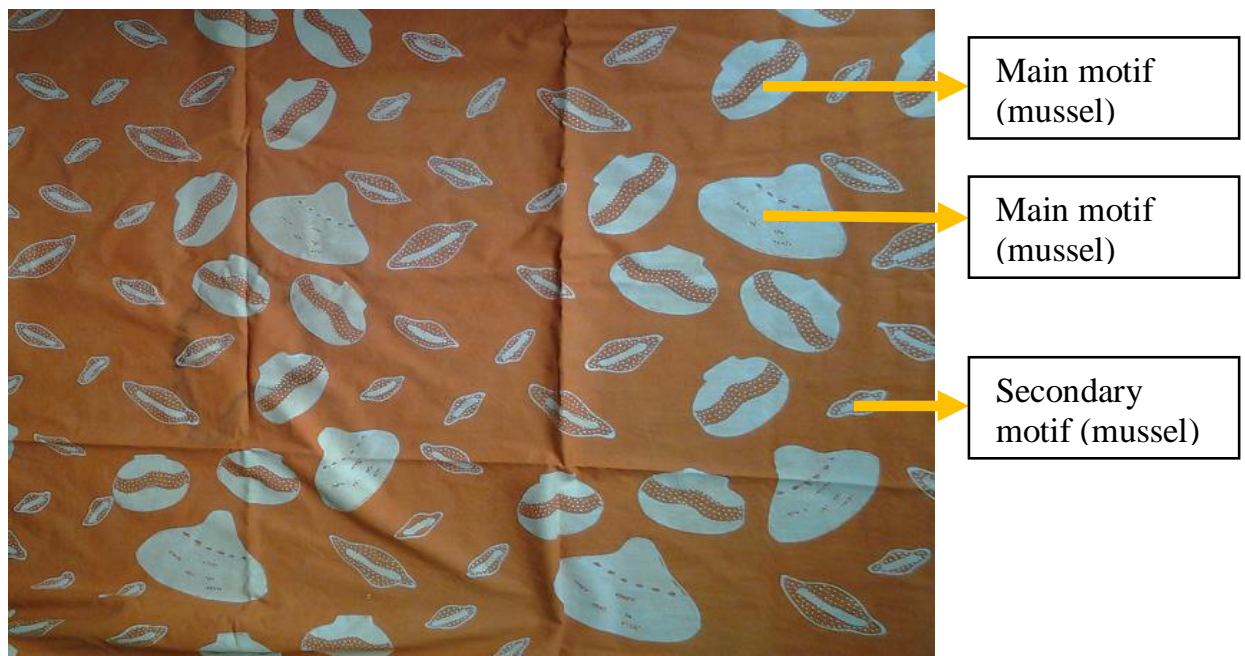

Figure 3. Design 1

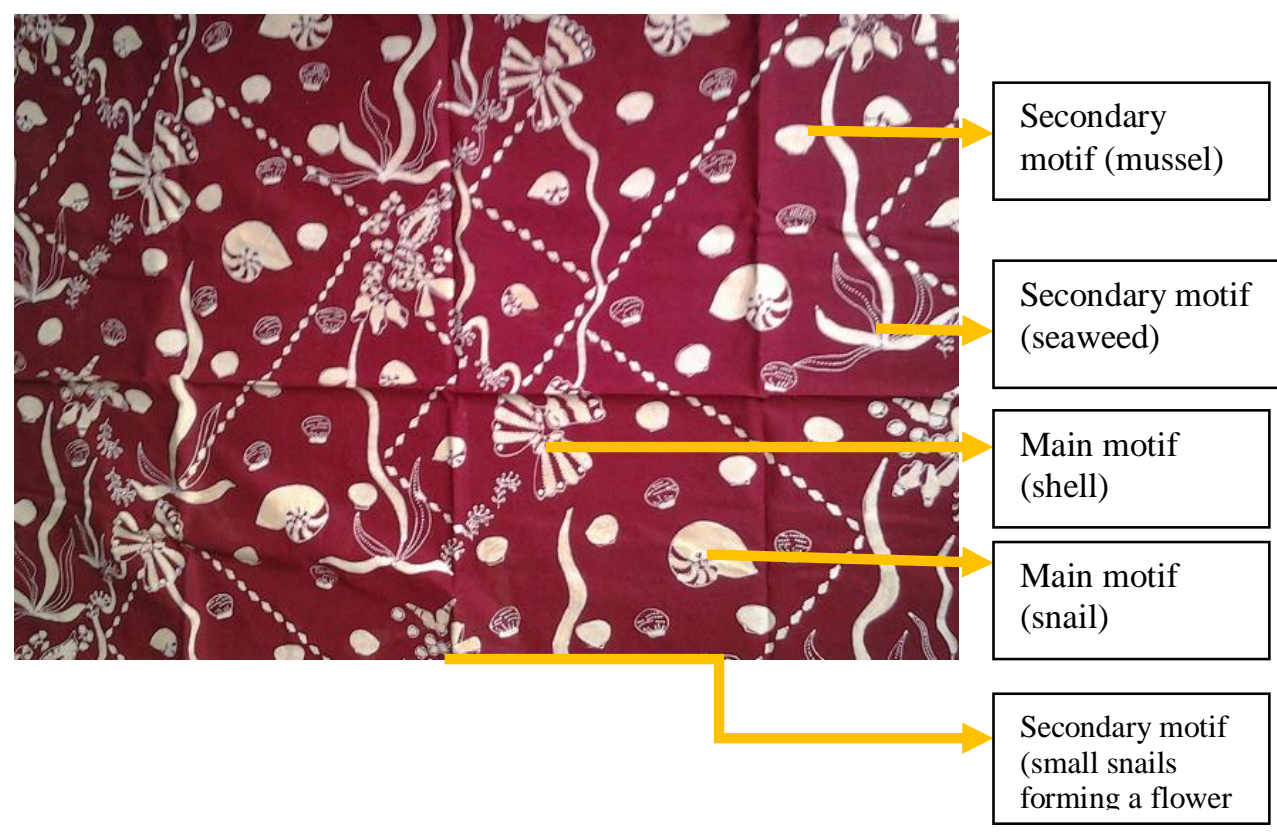

Figure 4. Design 2 


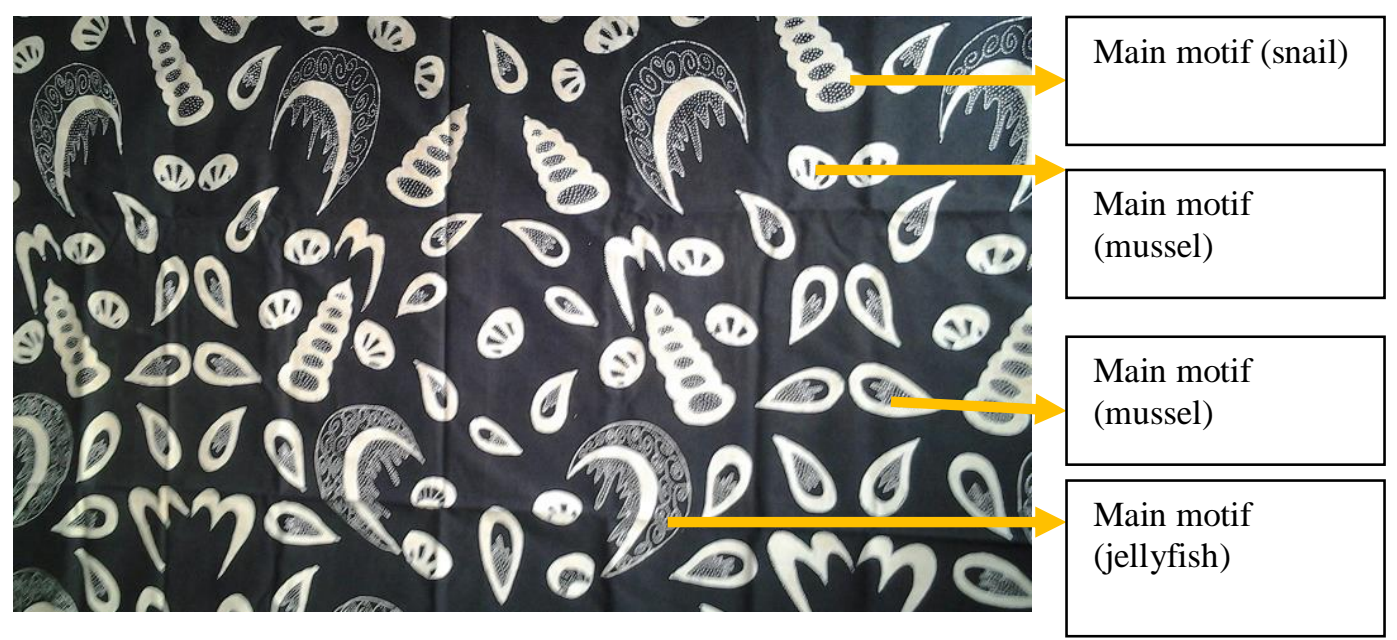

Figure 5. Design 3

By referring to the above designs, the results were evaluated using instruments and assessed by 100 consumers to find out the results of attractive batik design.

Table 1. Results of Consumer's Responses

\begin{tabular}{lccc}
\multicolumn{1}{c}{ Items } & Design 1 & Design 2 & Design 3 \\
\hline A. Main Motifs & & & \\
Varieties & $64 \%$ & $14 \%$ & $22 \%$ \\
Location & $13 \%$ & $78 \%$ & $9 \%$ \\
Size & $26 \%$ & $16 \%$ & $58 \%$ \\
Repeatation of the main motifs & $62 \%$ & $15 \%$ & $23 \%$ \\
B. Secondary Motifs & & & \\
Shape & $11 \%$ & $72 \%$ & $17 \%$ \\
Location & $24 \%$ & $66 \%$ & $10 \%$ \\
Size & $21 \%$ & $64 \%$ & $15 \%$ \\
Repeatation of the secondary motifs & $38 \%$ & $45 \%$ & $17 \%$ \\
C. Additional Motifs & & & \\
Varieties & $70 \%$ & $14 \%$ & $16 \%$ \\
Size & $61 \%$ & $22 \%$ & $17 \%$ \\
Repeatation of the additional motifs & $45 \%$ & $38 \%$ & $17 \%$ \\
D. Fabric Color & & & \\
Color combination & $48 \%$ & $32 \%$ & $20 \%$ \\
\hline
\end{tabular}

The results of the evaluation could be revealed that batik motifs based on consumer's needs included several considered aspects namely:

1. The most preferred batik design by consumers included the use various and small patterns placed in scattered locations.

2. Varieties of Motifs:

a. Shape: referring to the existing motifs that became the batik craftsmen's characters and trends.

b. Size: using medium size pattern, balanced between the main, secondary, and additional motifs. c. Layout: being placed anywhere as long as it was not too monotonous.

d. Repeatation: Repetition of the motifs could be used for the main, secondary and addtional motifs.

e. Fabric Color: the basic color of the fabric used secondary and tertiary colors but tent to be different than the color of the motifs.

From the evaluation results based on consumers' needs, the batik design was then developed using natural dyes namely soil. 
Development of Consumer-oriented Soil Batik Designs

Development of soil batik designs

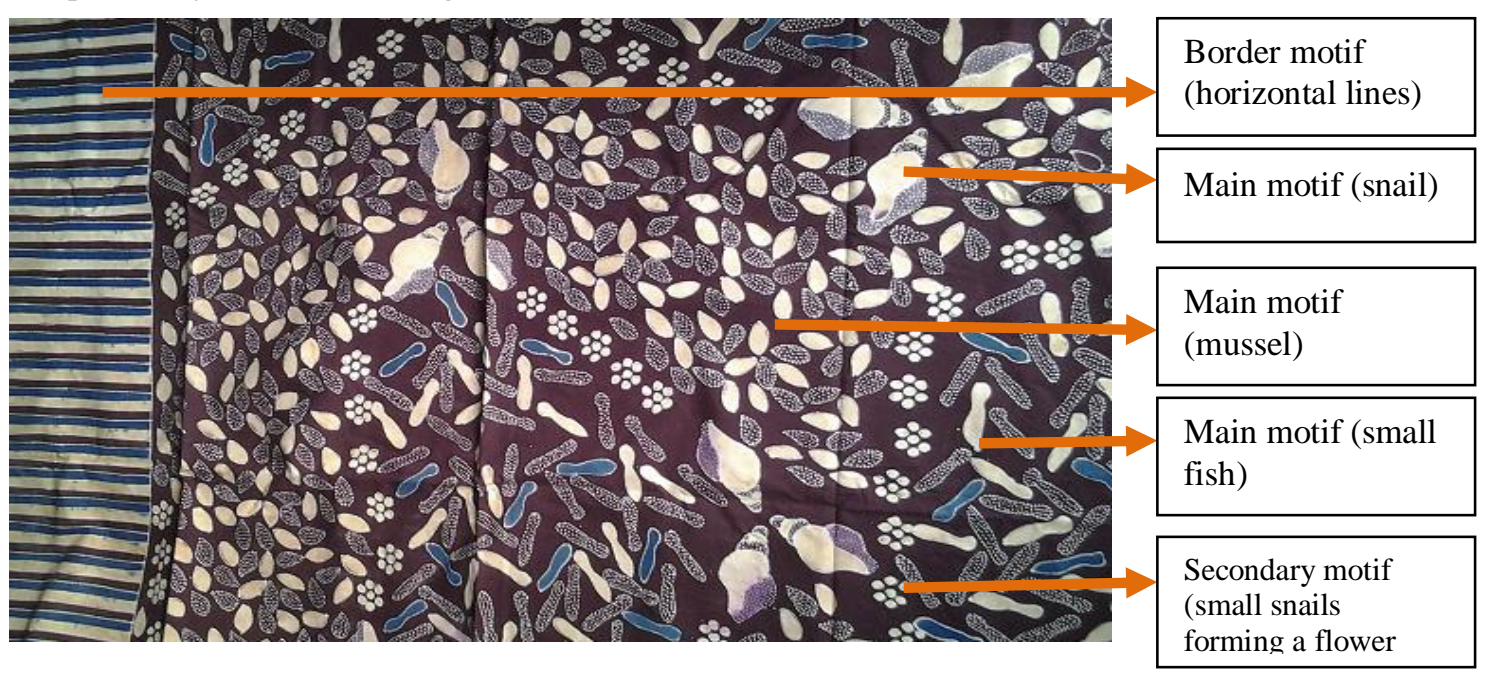

Figure 6. Design 1

Design 1 used a variety of ornamental marine living creatures such as mussel, small fish, and snails with varying sizes. Some kinds of decorative colors were painted using synthetic dyes as a center of interest.
Meanwhile, the borders used decorative horizontal placed in the edge of the fabric. The basic color of the fabric used a deep red color.

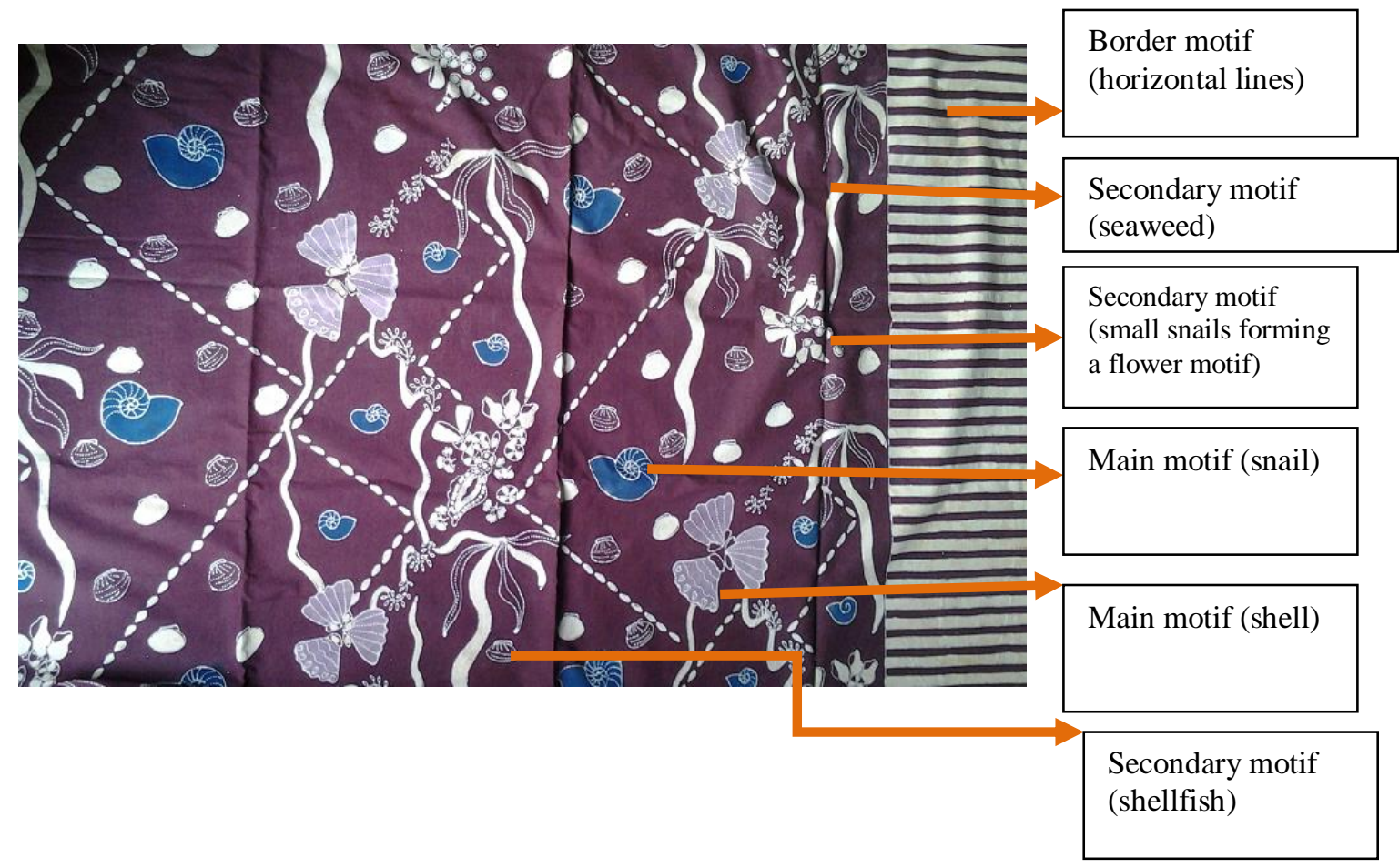

Figure 7. Design 2

Design 2 was developed using shell and snail shapes that varied in size. The secondary motifs used a form of seaweed and dotted lines around the motifs. The decorative coloring technique still used a combination of soil and synthetic colors. The base of the fabric also used the same color namely dark purple-red. 


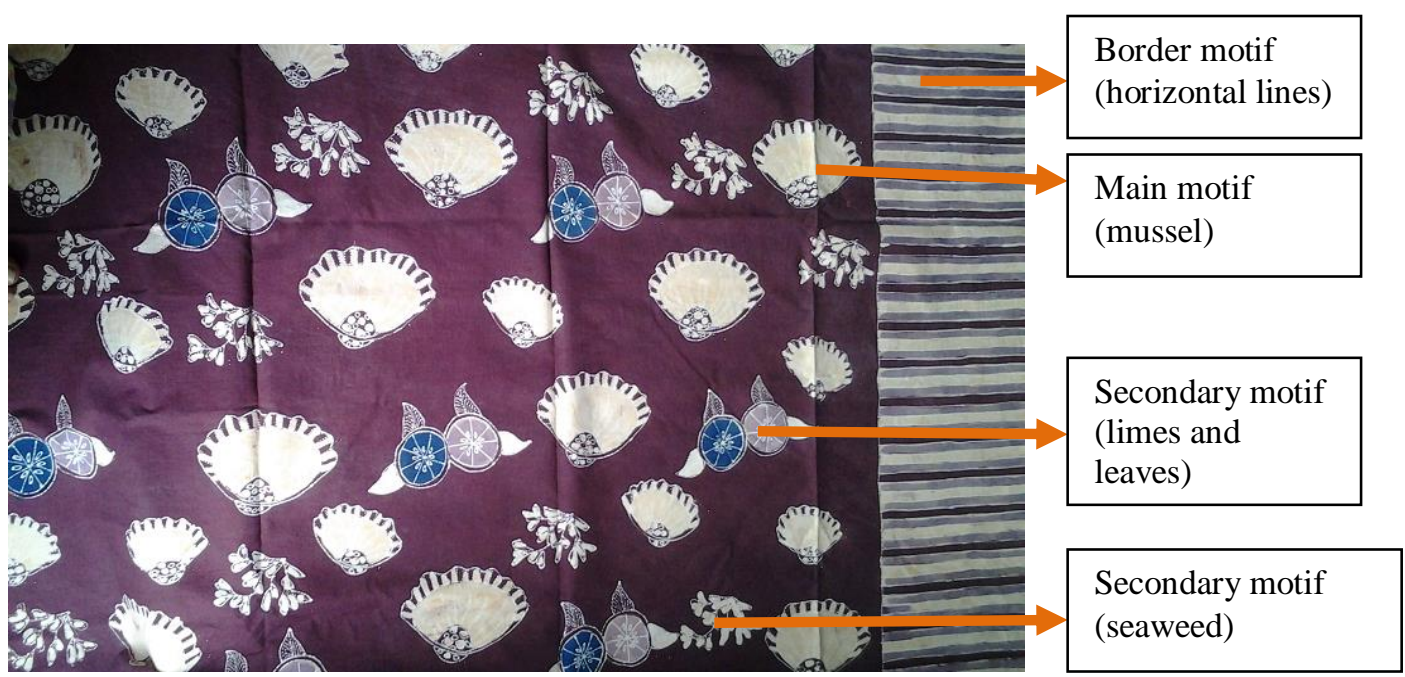

Figure 8. Design 3

Design 3 used the decorative shape of shells and limes that were varied in size. The secondary motifs used seaweed shape with scattered location. The decorative colors used soil color supported by blue and purple colors from synthetic dyes. The border used horizontal lines with several colors. The basic color of the fabric used dark purple.

\section{DISCUSSION}

Based on the evaluation results of the observations conducted on batik consumers three times, discussions with batik designers and craftsmen who were subsequently arranged by the PKC and PKK, the data could be analyzed that the formulation of soil batik designs oriented to consumers' needs could be drawn as follows:

a. Shape: Referring to the existing motifs that became the batik craftsmen's characteristics and trends, to attract the consumers' interest, the designers must always innovate both in the source of ideas and creativity. The variety of innovations could be gotten from local culinary, regional culture, regional uniqueness, philosophy of the local community. This is in accordance with the opinion of Mrs. Lulut [8] who states that batik designs should contain culture, philosophy, interesting and exclusive aspects that are not easily imitated.

b. Size: using medium size, balanced between the main, secondary, additional and border motifs. Medium motifs were more easily applied to various body shapes and proportions. The main motif was more dominant while the other motifs were smaller. The point was proportional and balanced between the types of motifs contained in the developed batik design.

c. Layout: decoration could be placed anywhere as long as it was not too monotonous. Laying the main motif must be a center of interest. In order to be more flexible, laying the varieties of motifs should be done in scattered method. This is in accordance with the opinion of Putu's mother [8], Saraswati batik owner, who states that Batik motifs should be made by considering its pattern layouts because it will limit the use of batik cloth for consumers.

d. Color: The colors for motifs were primary and secondary colors with a combination of different color compositions that tent to be analogous. When wearing batik, consumers wanted to look elegant so that the color combination was more likely to be wellcombined. For this reason, the color of soil as a natural color must be able to be the center of interest or be more prominent than the basic color of the fabric. According to the results of observations to consumers for ornamental variations, the use soil color was propagated or dominant in soil batik.

e. Fabric color: the basic color of the fabric used secondary and tertiary colors but tent to be older than the motifs' colors. The results of batik coloring using the soil color produced lighten colors such as beige, yellowish brown, and brick brown. Therefore, in order to be able to bring up these colors, good basic colors on soil batik were those with dark colors such as dark red, dark blue, purple, dark brown, dark green.

\section{CONCLUSION}

Development of soil batik designs based on consumers' needs include the development of the main, secondary, additional, and border motifs as well as the shape, size, color, and layout. The objectives of considering those aspects are the fact that the products can be sold and enhance the presence of Small Medium Enterprises' (SMEs) incomes. 


\section{REFERENCES}

[1] Adnyana, I Putu W., Kesiman. Made, Wahyuni, 2013, Pengembangan Aplikasi Pembuatan Pola Motif Batik dengan Menggunakan Pengolahan Citra Digital, JANAPATI Vol 1 Nomor 2 Juli 2013.

[2] Nateri, Ali S., Hajipour, A., Dehnavi, E., Ekrami, E., "Coloring Study on Polyamides Dyeing with Weld and Pemogranate Peel Natural Dyes", 2014, Clothing and Textiles Research Journal, Vol. 32.

[3] Bidayanto. Slamet, Anies, Purnaweni. Hartuti, Sunoko HR, 2018, Environmental Analysis of The Impact of Batik Waste Water Polution on The Quality of Dug Well Water in The Industrial Center of Jenggot Pekalongan City, ICENIS 2017, http://doi.org/10.1051/e3sconf/2018/20183 109008.

[4] Yulistiana, Russanti Irma, 2018, Soil Batik: The Innovations in Designing and Coloring, ASHHER Volume: 112.

[5] Gustami, SP., "Proses Penciptaan Seni Kriya: Untaian Metodologis", Program Pascasarjana S2 Penciptaan Dan Pengkajian Seni ISI Yogyakarta, 2004.

[6] Aprilia, Mamanda Gladies dan Martono, 2017, Relief Candi Mendut Sebagai Ide Dasar Penciptaan Batik Tulis Bahan Sandang untuk Busana Wanita, Jurnal Pendidikan Kriya Edisi Januari.

[7] Gustami, SP. 2007. Butir-Butir Mutiara Estetika Timur, Ide Dasar Penciptaan Seni Kriya Indonesia. Yogyakarta: Prasista.

[8] Russanti and Yulistiana, 2015, Inovasi Batik Lempung untuk Mendukung UKM Batik Sidoarjo, in Laporan Penelitian Hibah Bersaing (LPPM Unesa, Surabaya, Indonesia, 2013-2015. 